\title{
The Formula of Trumponomics
}

\section{The U.S. Reverts to Neomercantilism and Protectionism to Gather Strength for a New Breakthrough}

\author{
Alexander V. Losev
}

\section{Abstract}

This article examines the global problem of the ongoing transformation of the U.S. policy from globalization to neomercantilism and protectionism-in particular, the reasons why one of the results of deep structural changes in the world economy is the erosion of the U.S. hegemony and the rise of political competition in the world.

The author analyzes this change in the context of the transfer of management functions from the state to corporations and central banks in the post-industrial economies.

The article attempts to answer two key questions:

1. Is Donald Trump right in pursuing a tough economic policy, or is there a real alternative to 'Trumponomics' that could strengthen the U.S. position in the growing global competition?

2. What economic policy is preferable for GDP growth and citizens' welfare: monetary or fiscal?

The author comes to the conclusion that Trump's rise to power was not a domestic political irregularity or the result of foreign influence on American democra-

Alexander V. Losev is CEO of Sputnik Assets Management, JSC.

e-mail: alosev@sputnik-am.ru

Sputnik Assets Management, JSC

Floor 10, BTs Pollars, Bldg. B, Derbenevskaya Naberezhnaya 11, Moscow 115114, Russia

E-mail:am-sputnik@sputnik-am.ru

This article is greatly expanded and revised version of the paper written for the Valdai International Discussion Club. The original copy is available at: $h t t p: / / r u . v a l d a i c l u b . c o m / a / v a l d a i-$ papers/valdayskaya-zapiska-87/?sphrase_id $=57934$ 
cy institutions, but a historical inevitability in the face of the global challenges facing the United States. Prospects of the U.S. losing economic leadership are discussed, together with domestic and foreign policies aimed to prevent that. The study was based on the analysis of macroeconomic data of the United States and major regions of the world, as well as on the analysis of monetary and economic cycles. The dynamics of GDP growth and its nominal values, as well as the dynamics of industrial production in the United States and in the macro-regions of the world were considered with GDP and GNP compared on a component basis.

Keywords: Trumponomics, neomercantilism, globalization, soft power, hard power, national interests.

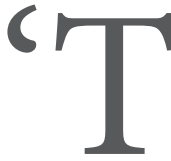

Trumponomics' is a popular term coined to describe the economic policy of the Donald Trump administration, based on fiscal reflation and rigid neomercantilism, aimed at developing industry and infrastructure, and supported by the return of corporate capital and an active "peace through strength" foreign policy.

\section{THE “GOLDEN AGE" OF GLOBALIZATION AND ITS COMPLETION BY 2016}

With the establishment of the United States' absolute leadership in the early 1990s, globalization became the main idea of the American elites. An integration process was launched to transform the structure of national economies and political relations between countries into geo-economy.

The world, with few exceptions, did not challenge the U.S. leadership and took for granted the American rules of the game and the system of global labor specialization. It agreed to a reduction of national sovereignty in favor of U.S.-controlled international organizations and institutions such as the IMF, the World Bank, the WTO, and the Exchange Stabilization Fund, to the transnationalization of financial markets, to the role of the U.S. Federal Reserve as the issuer of a world reserve currency, the dollar, to the rules of international trade, and unequal distribution of revenues. 
Each country that played by these rules derived benefits from globalization. It was globalization that ensured fast economic growth for most regions of the world and their accelerated technological development. The United States, as befits the leader, became the main beneficiary. The decades-long expansion of international trade earned it an additional one trillion dollars a year (Hufbauer and Jung, 2016).

However, the absence of serious political challenges to the U.S. leadership, economic globalization and the financialization of markets have resulted in geopolitics degenerating into geo-economics. Central banks have begun to influence economic processes, including the lives and incomes of citizens, corporations, budgets and economic cycles in their own and other countries, much more than democratically elected politicians and parliaments do, as stated in The Economist under the headline "The Wars of Independence" (Anon, 2017).

Whereas ten years ago the U.S. and the EU were the main contributors to global GDP, jointly accounting for 54 percent of it, now this figure has decreased to 45 percent. Simultaneously, the Asian megaregion (South and Southeast Asia) is ahead of the U.S. by 5.7 percent and ahead of the EU by 8.3 percent in terms of nominal GDP. The share of the Indo-Pacific region in global GDP is 30 percent, while that of the EU and the United States is 46 percent. At the same time, China's nominal GDP increased from $\$ 3.5$ trillion to $\$ 12.3$ trillion between 2007 and 2017, that is, 3.5 times over ten years.

Statistics show that the breakthrough occurred in 2016, when East Asian countries, in particular China, "the world's factory," became a new beneficiary of globalization (The World Bank, 2017). The United States suddenly realized that a time was coming when a continuation of current geo-economic processes would weaken American leadership and lead to a further growth of the Asia-Pacific region. The U.S. faced a growing trade deficit ( $\$ 566$ billion in 2017) and an increase in public debt to $\$ 21$ trillion.

\section{THE EROSION OF SOFT POWER}

The soft power of the U.S. and the attractiveness of democratic values in the world have been devalued by the liberalism of world trade, 
the transnationalism of financial elites, and the emergence of groups of supranational actors from among major corporations, investment funds and banks, as well as by changes in the direction of capital and resource flows. The ultra-high concentration of world production and labor resources in Southeast Asia and the accumulation of material values, technologies and financial reserves there have allowed China to claim full participation in the management of the global economy and globalization processes.

The hitherto unshakable Pax Americana has begun to erode. As Immanuel Wallerstein wrote in his analysis of world systems and the situation in the contemporary world, “The period from 1990 to 2025/2050 will most likely be short on peace, short on stability, and short on legitimacy. In part, this is because of the decline of the United States as the hegemonic power of the world-system" (Wallerstein, 1995).

\section{COMPONENTS OF NEOMERCANTILISM}

China is one of the most important actors in the new rivalry for world leadership. Therefore, it would be appropriate to quote the famous Chinese treatise The Art of War by Sun Tzu: "Disorder arises from order, cowardice arises from courage, weakness arises from strength. Order and disorder are a matter of organization, courage and cowardice are a matter of momentum, strength and weakness are a matter of formation" (Sun Tzu, 1991).

In the current geo-economic processes, three components of the formula of "the great matter of the state" - quantity, power, and formwill determine the final result.

Quantity is an emphasis on the growth of national welfare, the return of capital and its concentration in the home country, as well as the development of the domestic market to the detriment of allies and trading partners.

Power is military/political, financial and technological domination.

Form is the structure of the national economy, borders and barriers established around it, as well as a system of incentives, and expansion to foreign markets. 
All strategies of the United States and its competitors-major powers or state associations-will inevitably be built along these three lines, formulated by the great strategist of ancient China.

\section{DONALD TRUMP AS A RESPONSE TO THE DEMAND FOR A NEW ECONOMIC POLICY}

By the time of the 2016 presidential election, it had become clear that the U.S. would soon have to scale down its soft power policy and reduce the funding of allies due to a growing budget deficit, and that the promotion of democracy had led to the so-called "Imperial Overstretch" (Imperiale Überdehnung) (Münkler, 2005). Washington needs to place emphasis on hard power, with elements of military pressure, and on protectionism in order to slow down globalization, which helps China grow, and restore the manageability of geo-economic processes.

Economist Dani Rodrik in 1999 introduced the notion of the 'Globalization Paradox' and argued that there is a conflict between democracy, economic globalization, and national sovereignty. Rodrik insists that these three political goals cannot coexist at the level of nation state (Rodrik, 2011). He argues that we cannot have "deep economic integration" (he uses the term 'hyper-globalization'), national sovereignty (nation state), and democratic politics all at once (Rodrik, 2011: 200-201). We can have at most two out of three. Since democracy cannot be compromised, and he rejects the "global governance" option, he proposes a return to national sovereignty. He considers that global standards and regulations are not just impractical; they are undesirable. The democratic legitimacy constraint ensures that global governance will result in the lowest common denominator, a regime of weak and ineffectual rules (Rodrik, 2011: 204).

To retain its world leadership and continue its own policy at the national level, the United States would sooner or later have had to sacrifice globalization.

Restoring U.S. supremacy in the world required changes in Washington's policy, basically a different leader and a different ideology that would be far from neoliberalism. 
In fact, the United States needed to combine the Monroe Doctrine and Hans Morgenthau's idea that foreign policy must be based on national interest and that armed forces and the threat of their use are a major material resource in international relations, which determines the strength of a nation (Morgenthau, 1949).

It should be recognized that the Democratic Party did not have leaders for radical changes, nor politicians who could destroy the liberal world economic order. The success of the Republican Party was predetermined by the emerging circumstances of world processes.

Ideas expressed by Trump during the presidential campaign were the closest to the above requirements. Trump put forward protectionist views on industrial production and trade and populist ideas with regard to migrants. Stephen Bannon, chief executive of Trump's presidential campaign, claimed that the globalist elite was conspiring to undermine American sovereignty by supporting open immigration and free trade (Sarlin, 2017).

So, Trump's victory in the presidential election was predetermined by objective geo-economic processes, rather than the interference of "Russian hackers" or other external forces.

Unfortunately, the division of elites after the 2016 election prevents Trump from uniting internal political forces. Another preventing factor is that in the current geo-economic situation American Democrats and liberal media unintentionally serve the interests of China and some Asian and Latin American countries by opposing Trump and promoting liberalism in the style of the past. That is why the result of the political and economic experiment called Trumponomics is not at all obvious.

\section{MAJOR NATIONAL INTERESTS OF THE U.S.}

The U.S. National Security Strategy of 2017, a doctrinal top-level document prepared and approved in the first year of Trump's presidency, sets a "strategic direction for the United States that is meant to reassert America's advantages on the world stage and to build upon our country's great strengths" (National Security Strategy, 2017).

The Strategy clearly identifies the main national interests of the U.S.: to secure U.S. territory and protect the American people, the 
homeland, and the American way of life; promote American prosperity; preserve peace through strength; and advance American influence.

These four priorities have become the main ones in the Trumponomics formula, where quantity, power and form serve as arguments.

Whereas the defense of U.S. territory is an easy task which can be accomplished through huge budget allocations for the army, police, the National Guard, and security agencies, the other three tasks are related to the economy and are more difficult.

\section{"MAKE AMERICA GREAT AGAIN" OR "IT'S ECONOMY THAT MATTERS"}

Trump's economic program is based on fiscal reflation aimed at boosting demand and thus increasing the level of economic activity (Fleming and Donnan, 2016). Managing budget revenues and expenditures through amounts of taxes and government injections can smooth fluctuations in economic cycles and increase aggregate demand directly, by means of government orders and infrastructure projects, and indirectly, by increasing disposable incomes of companies and households, while reducing the tax burden, that is, taking less money from businesses and leaving more money to people, which they could use at their discretion.

The economic policy of the Trump administration includes economic stimulus measures aimed at increasing national production and GNP through a new budget and tax policy, which also implies a moderate monetary policy by the Federal Reserve and a marked reduction in the trade balance deficit.

A global competition with rising Asia requires that the U.S. strengthen its own production, improve the financial condition of companies and citizens and deprive its economic and geopolitical rivals of all advantages they have gained as a result of globalization.

It is important for the United States to retain control over technologies and intellectual property and concentrate on its territory industries, production chains, capital and resources, including basic ones-energy and raw materials.

Efforts to increase gross national income, improve the balance of payments, increase employment and exert pressure on competi- 
tors can be supported by a protectionist foreign trade policy, customs and technical barriers, and import restrictions. Protectionism will not help if the country does not have its own production in an amount required at least to meet domestic needs, and industrial facilities that need to be protected by imposing import restrictions. Therefore, Trumponomics implies a certain industrial policy, although U.S. industry, including the fuel and energy sector, produces only 21 percent of GDP, whereas the service sector accounts for 77 percent (The World Bank, 2017).

As instruments of economic policy, the administration has proposed increasing government spending, investing $\$ 1$ trillion in infrastructure and implementing a fiscal reform, estimated at $\$ 4.4$ trillion.

The Congress has approved a reduction in the corporate tax rate from 35 to 21 percent, tax deductions for capital expenditure, and a reduced tax rate for foreign-earned income returned to the United States from 35 to 15.5 percent for cash assets and 8 percent for non-cash assets. Taxes have also been reduced for some groups of individuals (ITEP, 2017).

Fiscal reflation increases aggregate demand and yields economic results in two ways. Firstly, households have more income left after taxes, which increases the demand for goods and services. Secondly, by allowing companies to deduct new investments from their financial results until 2022, the tax legislation stimulates them to increase shortterm investment, which boosts aggregate demand in the economy, this time on the part of legal entities.

\section{CALIFORNIAN “FRONDE"}

Unfortunately, the Trump administration has certain difficulty interacting with high-tech companies of the Silicon Valley, which is the center of the liberal spirit and the Democrats' "patrimony."

The point is that, in order to maintain high economic growth rates, the state needs technological leadership of its corporations, which is based not only on production volumes and close ties with the government, as, for example, in the military-industrial complex, but also on active research funding and constant introduction of innovations. It is 
innovations that shape the development of all world production, ranging from consumer goods to military equipment.

Without contacts with scientific and business elites, who act as a kind of "Fronde" against Trump, his administration will find it difficult to ensure ever higher labor productivity required to maintain economic growth rates.

\section{GROWING DEBTS AND BUDGET DEFICIT}

The federal budget deficit was the greatest under Trump's predecessor, Barack Obama. By the end of his presidential term, the deficit had risen to $\$ 6.69$ trillion. Obama took office during a crisis and had to spend billions of dollars to stop the recession, although budget tax revenues decreased. He convinced the Congress to add a $\$ 787$ billion stimulus package to the 2009 federal budget. The American Recovery and Reinvestment Act added another $\$ 534$ billion. By 2010, tax incentives introduced by Obama had increased the national debt by $\$ 858$ billion, and defense spending added up to $\$ 800$ billion a year to the debt. Social security and Medicare expenditures required more federal spending.

Trump inherited a bloated budget and a colossal public debt from Obama. The budget deficit keeps growing, but this time due to Trump's own fiscal policy.

The U.S. federal budget for fiscal year 2018, named "America First: A Budget Blueprint to Make America Great Again," was approved with a deficit of $\$ 833$ billion.

In fiscal year 2019, the federal budget will amount to $\$ 4.407$ trillion, with revenues reaching $\$ 3.422$ trillion. This leaves a deficit of $\$ 985$ billion (Budget, 2018).

There is a serious problem here. Issuing more treasury bonds to cover the budget deficit caused by shortfalls in income may bring shortterm interest rates to three percent already in late 2019, which will impede investments. That is why tax measures are limited in time. After 2025, the government is expected to reduce the federal budget deficit and lower interest rates, which will again stimulate investment as positive effects for industrial production will be exhausted by that time. 
To stimulate domestic production, the government plans to introduce various protectionist measures, including duties on imports of broad categories of goods from major trading partners of the United States. These goods include not only metals but high value-added products, such as cars, electronics and household appliances.

In the next few years, GDP growth and expansion of the tax base will not compensate for shortfalls in budget revenues due to a reduction in nominal tax rates, while infrastructure projects have long payback periods.

These factors will inevitably lead to reductions in federal revenues, a further increase in the federal budget deficit, and an increase in the state debt by almost $\$ 11$ trillion before 2027 .

By the end of the first half of 2018, the public debt had reached $\$ 21.4$ trillion or 105 percent of GDP. By 2020, the debt/GDP ratio may reach 110 percent, despite a planned increase in the economic growth rate from 3 to 5 percent per year (TreasuryDirect, 2018).

The Joint Committee on Taxation estimates net losses from the adoption of the law at $\$ 1.414$ trillion over ten years. According to the Congressional Budget Office and the Senate Finance Committee, the tax reform will lead to a budget deficit of $\$ 1.441$ trillion and a revenue decrease of $\$ 1.633$ trillion.

To reduce the budget burden, the government has proposed measures, such as deregulation of the economy and repeal of the health care reform (Obamacare). However, it will not be able to quickly reduce health care costs, especially on the eve of a congressional election, as this measure will affect a broad range of voters. Medical services are a sector of the economy that generates 16 percent of GDP and provides jobs for more than 10 million people (Statista, 2017a).

Under Obama, social welfare expenditure reached 66 percent, compared to 15 percent in the middle of the twentieth century. This "socialism" in a country that was viewed as the bulwark of capitalism throughout last century creates very high risks for the economy in the future.

But there is also good news: taxpayers' incomes may increase by an average of eight percent, which in turn will increase the tax 
base. As a result, the U.S. federal government may earn an additional $\$ 566$ billion in tax revenues from individuals and $\$ 683$ billion in payroll taxes.

If corporate taxes continue to decline fast, this reform will stimulate investment growth and will allow businesses to deduct more money for capital investment. Moreover, in order to stimulate investment lending, the Trump administration plans to convince the Congress to repeal the Dodd-Frank Act, which significantly limited the activities of commercial banks after the 2008 crisis.

The aforementioned measures will allow U.S. companies to save $\$ 1.2$ trillion during the first years of the reform and another $\$ 1.3$ trillion by 2025 (Li and Pomerlau, 2018).

If Trump's tax reform proceeds according to plan, the reduction of the tax burden on investment and labor will add nine percent to GDP growth in the long term, according to Congressional experts.

\section{TOP PRIORITY GOALS OF TRUMPONOMICS}

The primary goals of Trumponomics are the development of domestic production, improvement of the labor market, and return of American capital from offshore areas.

Seventy percent of U.S. GDP is generated by domestic consumption. A population of more than 320 million makes the U.S. consumer market huge. This means that the United States has good potential for import substitution. Another very important problem that increases economic risks if interest rates keep growing is a high level of household debt. The total personal debt stands at \$19 trillion, or 95 percent of GDP (Statista, 2017b).

This is why a proposal to create new jobs and improve living standards only for U.S. citizens and to give full-time employment to part-time workers seems logical. The share of the economically active population in the U.S. is now 62.9 percent of the total number, or 159.7 million people (Trading Economics, 2018a). In the last year of Obama's presidency, the number of foreign workers (legal and illegal labor migrants) was estimated at 27 million of the total of 44.7 million migrants (Lopez and Bialik, 2017). Meanwhile, the Bureau of Labor 
Statistics data (up to the first quarter of the year 2014) showed that there were some 58 million working-age (16 to 65) native-born Americans not working (Camarota and Zeigler, 2014).

The purpose of economic growth requires that the U.S. limit the involvement of migrants in the economy-firstly, because they are ready to work for smaller wages than Americans, and secondly, because their remittances to their home countries are subtracted from U.S. GDP, while Mexico alone, for example, receives $\$ 20$ to $\$ 30$ billion of these remittances a year.

Therefore, proposals to strengthen the border with Mexico and tighten anti-immigration legislation are not a whim of unpredictable Trump, as his ideological opponents believe, but a real necessity.

The U.S. also needs to remove existing imbalances in international trade. That is why it repeatedly proposes revising international trade agreements and even threatens to withdraw from the WTO.

Washington's foreign policy should serve national interest-this is one of the basic postulates of Trumponomics. This policy includes imposing decisions on allies and satellites, for example, restricting cooperation of American corporations and those from allied countries with countries mentioned in the Countering America's Adversaries Through Sanctions Act in sensitive areas.

In most countries, U.S. goods are subject to VAT, whereas in the United States imports are not charged VAT, with the exception of sales tax in some states. The U.S. plans to redress this imbalance by gradually introducing new duties on imported goods and introducing asymmetric taxation for its exporters and importers, so that the difference in tax rates negates the main advantages of U.S. trading partners if they suddenly decide to engage in dumping or resort to competitive devaluation of their own national currencies.

Another problem is that most American manufacturers depend on imported components; meanwhile, 95 percent of all clothing and footwear sold in the U.S. is made abroad. This is why measures to return industrial production to the United States, where labor is more expensive and taxes are higher, or to introduce import duties will lead to higher prices for products made in the U.S. using imported 
materials and boost inflation. These factors will create difficulties for the textile, chemical, and automotive industries, processing companies, and even legal and financial cross-border services. The rise in inflation will increase interest rates, which will negatively affect economic activity.

\section{IMPORTS HOLD BACK U.S. ECONOMIC GROWTH}

Currently, the American economy goes though a sort of "isothermal process, when the increase in the "enthalpy" of consumer demand due to budget incentives leads not to the growth of the domestic economy, but to a mere acceleration of the exchange of surplus income for imported goods. For the fiscal incentives to have a positive effect it is necessary to reduce foreign trade by transferring the process from the notional "isothermal" to relative "adiabatic" - so that the work needed to change the volume of domestic production would create a driving moment in the economy.

Although the introduction of import tariffs and duties boosts inflation and negatively affects production in many industries, the U.S. will have to impose strict import restrictions as imports hold back U.S. economic growth, as demonstrated by statistics during the first year of Trump's presidency. By the end of 2017, the imbalance in trade in favor of imports had reduced the GDP growth rate by 1.13 percent. The point is that the growth of U.S. citizens' incomes and their consumer activity leads to more imports. In 2017, the U.S. trade deficit increased by 12.1 percent to reach $\$ 566$ billion, a record high in nine years (Trading Economics, 2018b).

Import, which is subtracted from GDP growth, has increased the fastest over the past seven years. The growth of import, following the acceleration of the U.S. economy, highlights problems faced by the Trump administration in its desire to boost the GDP growth rate to 5 percent by the end of 2018.

Since the potential for import substitution is limited by the existing production capacity, the U.S. can reduce imports quickly only by introducing protective duties, establishing customs barriers and setting new technological requirements. 
These goals make China, "the world's factory," the main U.S. rival. Beijing has already been accused of "stealing American technologies and engaging in other unfair trade practices."

The high share of imports in the structure of domestic consumption and the annually growing trade deficit pose threats to sustainable economic growth. The constant trade deficit causes damage to the economy, since it is financed by debt. The U.S. can buy more than it produces because it borrows money from its trading partners.

Another problem related to trade deficit is the decreased competitiveness of the American economy. U.S. companies that buy goods abroad for a long period of time lose experience and production capacity; therefore, they lose jobs and competitiveness.

That is why it should be expected that the Trump administration will step up its protectionist rhetoric and policy.

To justify the new tariffs, the administration has invoked a little-used provision of the Trade Expansion Act of 1962, which allows restricting imports for national security reasons (Trade Expansion Act, 1962).

This policy may increase the risk of full-scale trade conflicts. But from the point of view of tasks facing the American economy, a further escalation of trade wars is inevitable. In the first half of 2018, the U.S. trade deficit hit a record high $\$ 291$ billion, up from $\$ 272$ billion in the first half of 2017.

The introduction of tariffs or quotas will increase production costs in machine-building. American automakers already express concern that higher steel and aluminum prices may reduce their revenues, raise vehicle prices and decrease the demand for cars in the United States. Statistics show that growth in the automotive industry has begun to slow down in 2018 and some industries are already experiencing a short-term decline. The administration plans to respond to these negative developments by imposing tariffs on imported cars.

\section{SUPPORT FOR POWER ENGINEERING SECTOR AND BASIC INDUSTRIES}

The U.S. economy is well provided with domestic natural resources, so the immediate goal of Trump's industrial policy is to support basic 
industries such as power engineering, the oil and gas sector, transport and heavy engineering, and the mining and smelting industry.

These sectors are planned to be supported by protective measures and customs tariffs. The economic program gives special importance to the energy policy and energy security. The United States is the largest energy consumer in the world. The U.S. accounts for 25 percent of the world's electricity consumption, which is commensurate with the U.S. economy's weight in the gross world product. Daily oil consumption in the U.S. is 19.7 million barrels, and oil production in the country in March 2018 reached 10.3 million barrels. However, this still makes only 52 percent of the demand, and the country has to import the remaining 48 percent of oil. The administration has to take this ratio into account -68 percent of imported oil is now exempt from duties. But in the future, if the U.S. becomes capable of meeting 75 percent of its demand for oil and oil products with its own resources, it may well introduce import duties on oil.

The improvement of natural gas liquefaction technology will lead to the globalization of the gas market, which will open up export prospects for American LNG. We will see struggle for consumer markets in Europe and Asia with the use of economic and military-political levers. Europeans already experienced that in the summer of 2018 when they discussed with Trump the Nord Stream 2 gas pipeline from Russia. Also, China has been asked to increase imports of American LNG in order to reduce the imbalance in bilateral trade.

\section{LONG-TERM GOALS AND NATIONAL INTEREST}

The United States will try to create a kind of autarky in its territory in order to ensure growth of its national wealth and concentration of capital, resources and production capacities, fully meet domestic needs and depend less on imports of goods or raw materials, especially critical ones. The priority objective of the industrial policy is support for the creation of a dynamic domestic manufacturing sector. To meet this goal, the U.S. has also sharply increased defense spending and allocations for the military-industrial complex. The Pentagon's base budget for 2019 is to be $\$ 716$ billion, but, taking 
into account the budgets of the National Guard, Intelligence, and the Department of Veterans Affairs, the defense budget may reach U.S. $\$ 897$ billion.

The U.S. plans to achieve energy independence by 2025 and concentrate on its territory not only research centers and agencies for the development of new technologies, but also production facilities where innovations will be introduced and turned into basic technologies of a new industrial paradigm.

Trumponomics will seek to create conditions for returning industries that are key to national security to American territory. Simultaneously, the U.S. foreign policy will be aimed at creating hotbeds of tension in various regions of the world in order to increase supplies of U.S. arms and military equipment to allies. In this way, Trump's "peace through strength" concept will help mobilize industry and transform the economy to enable its transition to a new technological paradigm.

\section{POSITIVE CHANGES IN THE ECONOMY}

Economic statistics show that since President Donald Trump's inauguration the state of the American economy has improved: it has become more stable and demonstrates the fastest economic growth among developed countries. Growth points have formed mainly in the sphere of consumer spending and investment in business expansion.

Unemployment has dropped to the lowest point in the past 50 years. Jobs are also created in the so-called "Rust Belt" of America. In the first year of Trump's presidency, the revival of production, construction and mining in this region led to an increase in the number of jobs by almost half a million. American companies have created more jobs than projected, which is a sign that the labor market remains healthy. ADP data (ADP, 2018) indicates a transition from part-time to fulltime employment and a growing demand for experienced workers. ADP points out that young people are in demand on the labor market, due to which the U.S. favorably compares with other developed countries, especially the European Union. Based on the ADP data, Moody's concludes that "2018 is on track to be the eighth consecutive year in which the economy creates over 2 million jobs." 
The rise of share prices in the stock market, which involves in various ways about 60 percent of the economically active population of the United States, as well as rising real estate prices and wage growth, increase the welfare of households, as companies have begun to compete for skilled workers, and some states have increased the minimum wage at the local level. These factors will continue to support consumer spending.

The positive dynamics of real GDP, whose growth rate is close to 5 percent, confirms the positive effect of growth in consumer spending by the population and businesses, and of investment in commercial real estate and fixed assets. Increased costs of the federal government and municipalities have been partially offset by reduced investment in inventories.

Consumer spending, which accounts for more than two thirds of U.S. economic activity, had reached $\$ 11.8$ trillion by the end of 2017, although 65 percent of this spending was made by the service sector. Housing and health were the largest components of consumer spending, each standing at $\$ 2$ trillion (FRED, 2018; BEA, 2018).

The high domestic demand is supported by expectations of a prolonged positive effect from tax cuts. Higher levels of consumption in the short term lead to GDP growth, but longer-term growth requires a higher saving rate, which has not yet been observed.

The increased consumer demand for manufactured goods is largely met by imports, and these statistics will only spur protectionism.

\section{TRADE WARS}

One of the postulates of Trumponomics is the recognition of the fact that in the global market the United States does not have partners to cooperate with but rivals with whom it will have to compete, defending American economic interests.

This attitude will have very negative consequences for world trade, estimated at 55 percent of global GDP, and for multilateral trade agreements.

A potential trade war will hit the hardest countries whose exports of value-added goods to the U.S. account for a large part of its GDP 
and which have a high share of manufacturing in national production and a large surplus in trade with the United States. In absolute terms, China accounts for about half of the entire U.S. deficit, followed by Japan, Germany, and Mexico. Trade statistics suggest that Trump's protectionist policy will also affect Canada, the EU, Brazil, South Korea, Turkey, and Russia.

Many analysts believe that the main goal of Trump's trade war is to reduce the deficit in trade with China. Restrictive measures will affect the sectors of information and digital technologies, communications, cyber-physical systems, medical equipment, aerospace manufacturing, machine tool production, machinery, electric vehicle production, etc. These measures are aimed not only at reducing the record high deficit in U.S. trade with China but also at slowing down China's transition to Industry 4.0.

China's response may affect the U.S. agro-industrial complex and the spheres of consumer goods, technology, services, and education. China may restrict the participation of U.S. companies in its government procurement program, specifically as regards aviation equipment, which would be bad news for the Boeing Company.

There is small chance of a serious escalation of trade war in 20182019. The main risk for the world economy stems from a reversal of the credit cycle and money supply by the U.S. Federal Reserve and the world's leading central banks.

The U.S. economy is still tied to the economies of other countries through a complex global chain of supplies of raw materials and goods, as well as mutual investment. U.S. foreign direct investment in China is five times larger than that of China in the United States. The People's Bank of China is one of the largest holders of U.S. Treasury bonds. Given the financial interconnection between the two economies, it can be concluded that a trade war will be counterproductive. Most likely, the Trump administration will try to pressure China into buying more American goods and services. Europe is a relatively closed economy; so, it is more or less protected against global trade wars.

It is easier to introduce tariffs and create barriers than discuss problems in dispute settlement bodies of the World Trade Organiza- 
tion, especially as the U.S. itself has done a lot to weaken the WTO. Some industry officials from U.S. trading partners believe that if exports fall, the market may become oversaturated in the medium or long term, leading to a serious economic crisis. As a rule, tariffs hit manufacturing sectors. Industrial production accounts for 80 percent of all international trade, but in the United States production makes only 12 percent of GDP; so, the U.S. is in a better situation than China, Japan or Germany.

Developing countries will be the biggest losers in a trade war, as a slowdown of international trade would have the greatest impact on their exports and industrial production.

\section{CONCLUSIONS AND EXPECTATIONS}

In 2018, the U.S. share in global GDP stands at 23 percent, whereas in 2000 it made almost one-third, 32.5 percent, a decline of 29 percent over 18 years. This is a large and serious decrease. The U.S. is followed by China, the only contender for world leadership in the foreseeable future, with 15 percent. If China maintains its current growth rate, it will surpass the U.S. in nominal GDP in the next decade. The United States can no longer afford to bear the entire burden of obligations to the world, which it assumed when it became the only hyperpower a quarter of a century ago.

Globalization American-style has reached its natural limits, and now China and Asia as a whole are becoming the main beneficiaries of world development. We are witnessing the growth of neomercantilism, protectionism and regionalization in the world, which is slowly returning to the situation of a hundred years ago, to what resembles the decade before World War I.

The United States will now have to rely more and more on military power and 700 military bases and strongholds scattered around the world.

Globalization will be stopped by a series of military and trade conflicts in various regions of the world. The struggle for energy resources will also provoke conflicts at the regional and global levels. The strengthening of the military component in the U.S. National Security 
Strategy suggests that America has almost no time to solve emerging problems and respond to emerging challenges using economic tools, as it used to in the early 21 st century.

Maintaining its influence by means of soft power and the buying allies' loyalty are becoming very expensive for the United States and lead to global overstretching.

America will try to isolate itself from the world and accumulate strength on its territory for a new breakthrough, retain its superiority in the future and create conditions for securing its leadership in the new technological paradigm and Industry 4.0.

A poly-sectoral structure of the economy, borders and barriers established around it, a high level of technological development, financial and military-political independence, a domestic demand stimulation system, and a strategy of expansion to foreign markets will make the United States immune from external influences, regional crises and barriers erected by third countries, even if they are very strong economically or militarily and politically.

The U.S. problem is that Trump's plans do not provide for the financing of scientific research in amounts comparable to those allocated in the Cold War era. Soon, along with competition in international trade, there will arise the issue of competition with China in engineering and science.

The United States will try to gain the most from the new global confrontation if things do not go too far and do not pose existential risks for the entire human civilization.

In the foreseeable future, a return of production to the U.S. from developing countries will adversely affect world trade and damage competitors and the global economy as a whole. The United States may increase its share in world markets, but its spending, including defense spending, will increase. The main task for the U.S. now is to maintain its military-technological leadership. Part of the costs for these efforts will be shifted to allies and satellites.

The tax reform will have a long-term positive effect on the economy, but there will be negative consequences for the U.S. budget. 


\section{References}

ADP, 2018. July 2018: ADP Employment Reports. ADP Research Institute [online]. Available at: <https://www.adpemploymentreport.com/> [Accessed 30 August 2018].

Anon., 2017. How to preserve the benefits of central bank-autonomy. The Economist. The wars of independence [online]. April 27, 2016. Available at: <https://www.economist.com/leaders/2017/04/27/how-to-preserve-thebenefits-of-central-bank-autonomy> [Accessed 28 August 2018].

BEA, 2018. Consumer spending. Bureau of Economic Analysis. U.S. Department of Commerce [online]. Available at: <http://www.bea.gov/data/consumerspending/main $>$ [Accessed 30 August 2018].

Budget, 2018. Budget of the U.S. Government. Fiscal Year 2019. Office of Management and Budget. U.S. Government Publishing Office, Washington [online]. Available at: <https://www.whitehouse.gov/wp-content/uploads/2018/02/ budget-fy2019.pdf> [Accessed 29 August 2018].

Camarota, S. and Zeigler K., 2014. All employment growth since 2000 went to immigrants. Center for Immigration Studies, June 14, 2014 [online]. Available at: <https://cis.org/All-Employment-Growth-2000-Went-Immigrants> [Accessed 31 August 2018].

Fleming, S. and Donnan, S., 2016. Trump's economic policy explained: the era of fiscal restraint is over. Financial Times, 10 November [online]. Available at: <https://www.ft.com/content/b5b78c76-a769-11e6-8898-79a99e2a4de6> [Accessed 30 August 2018].

FRED, 2018. U.S. Personal Consumption Expenditures. FRED Economic Research [online]. Available at: <https://fred.stlouisfed.org/series/PCE> [Accessed 30 August 2018].

Hufbauer, G.C. and Jung E., 2016. Why has trade stopped growing? Not much liberalization and lots of microprotection. Peterson Insitute for International Economics report. Trade and Investment Policy Watch, 23 March, [online]. Available at: <http://www.imf.org/external/pubs/ft/fandd/2016/12/mallaby. htm $>$ [Accessed 28 August 2018].

ITEP, 2017. The final Trump-GOP Tax Bill: national and 50-states analysis. Institute on Taxation and Economic Policy, December. [online] Available at: $<$ https://itep.org/finalgop-trumpbill/> [Accessed 29 August 2018]. 
Li, H. and Pomerlau, K., 2018. The distributional impact of the tax cuts and jobs act over the next decade. Tax Foundation Fiscal Fact. No. 596, June. [online]. Available at: <https://files.taxfoundation.org/20180628130358/Tax-Foundation-FF596.pdf> [Accessed 29 August 2018].

Lopez, G. and Bialik. K., 2017. Key Findings about U.S. immigrants. Pew Research Center [online] 3 May. Available at: <http://www.pewresearch.org/ fact-tank/2017/05/03/key-findings-about-u-s-immigrants/> [Accessed 30 August 2018].

Morgenthau, H., 1949. The primacy of the national interest. The American Scolar, 18(2) Spring, pp. 207-212 [online] Available at: <https://www.jstor.org/ stable/41205156?seq=1\#page_scan_tab_contents> [Accessed 29 August 2018].

Münkler H., 2005. Die Logik der Weltherrschaft - vom Alten Rom bis zu den Vereinigten Staaten. Rowohlt: Berlin Verlag.

National Security Strategy, 2017. National Security Strategy of the United States of America. [pdf] Available at: <https://www.whitehouse.gov/wp-content/uploads/2017/12/NSS-Final-12-18-2017-0905.pdf> [Accessed 29 August 2018].

Rodrik D. The Globalization Paradox. Democracy and the Future of the World Economy. W.W. Norton \& Company, 2011.

Sarlin, B., 2017. Steve Bannon touts Trump's 'economic nationalist agenda' NBCNews, 24 February. [online] Available at: <https://www.nbcnews.com/ politics/politics-news/bannon-touts-trump-s-economic-nationalist-agendan724851> [Accessed 29 August 2018].

Statista, 2017a. Health care in the United States. Statista, The Statistics portal [online]. Available at: <https://www.statista.com/statistics/184968/us-healthexpenditure-as-percent-of-gdp-since-1960/> [Accessed 29 August 2018].

Statista, 2017b. U.S. GDP-statistics \& facts. Statista, The Statistics portal [online]. Available at: <https://www.statista.com/topics/772/gdp/> [Accessed 29 August 2018].

Sun Tzu. The art of war. Translated by Thomas Cleary. Shambhala Pocket Classics. Boston, 1991 [online] Available at: <http://web.mit.edu/ dcltdw/AOW/5. html> [Accessed 28 August 2018].

The World Bank, 2017. World Development Indicators: Structure of output. The World Bank Data. [online] Available at: <http://wdi.worldbank.org/table/4.2> [Accessed 30 August 2018]. 
The World Bank, 2017. GDP (current U.S.\$). World Bank national accounts data, and OECD National Accounts data files [online] Available at: $<$ https://data. worldbank.org/indicator/NY.GDP.MKTP.CD > [Accessed 28 August 2018].

Trade Expansion Act, 1962. Section 232 of the Trade Expansion Act of 196.2 [online] Available at: <https://www.gpo.gov/fdsys/pkg/STATUTE-76/pdf/ STATUTE-76-Pg872.pdf> [Accessed 30 August 2018].

Trading Economics, 2018a. United States Employed Persons. TradingEconomics. com Available at: <https://tradingeconomics.com/united-states/employedpersons $>$ [Accessed 30 August 2018].

Trading Economics, 2018b. United States Balance of Trade. TradingEconomics. com Available at: <https://tradingeconomics.com/united-states/balance-oftrade $>$ [Accessed 30 August 2018].

TreasuryDirect, 2018. The debt to the penny and who holds it. TreasuryDirect [online]. Available at: <https://www.treasurydirect.gov/NP/debt/current> [Accessed 29 August 2018].

Wallerstein, I., 1995. Peace, stability, and legitimacy, 1990-2025/2050. In: After Liberalism. New York: The New Press, 1995, pp. 25-45. 